\title{
The Ghost Newspaper: Fake Journalism in the Mexican Drug War
}

\author{
FERNANDO MARTÍN VELAZCO \\ Writer, Stultifera Navis Institutom
}

\begin{abstract}
During the 2010s, Tamaulipas, a border state in northern Mexico, became a "silenced zone" for journalism as a result of the Mexican Drug War. In 2016, during an international theatre festival in the port of Tampico, the Stultifera Navis Institutom collective intervened at the headquarters of what used to be one of the most important journals in the city. The building, located in downtown Tampico, had been abandoned for thirty-three years. For three days, we brought the newspaper "back to life," using only fake news.

This essay recovers the experience of this multidisciplinary site-specific intervention by casting a critical look at its theoretical foundation in Jacques Derrida's concept of "Hauntology" and Georges Didi-Huberman's method of "Anachronism." Engaging deontological debates within media practice and the "virtuality" concept in literature, it analyzes the use of fiction as an act of discursive rebellion. Finally, "spectrality" and Aby Warburg's notion of "images in history" are problematized with a decolonial perspective, concluding with a reflection on the theatrical character of historical resurgences through an analysis of Shakespeare's Hamlet.
\end{abstract}

\section{INTRODUCTION}

On December 11, 2006, President Felipe Calderón ordered the display of thousands of soldiers in the streets of Mexico to combat the organized crime groups that dominated some parts of the country. That was the beginning of what has been called the Mexican Drug War.

The results have been catastrophic. Mafia groups diversified their activities, and the capture of the cartels' leaders provoked the growth of the number of criminal organizations and the brutality of their actions against civilians. For more than a decade, homicide rates in Mexico increased to their highest levels in a century, just as hijacks, disappearances, and extortions became quotidian occurrences. Each year, more than a thousand abductions are committed. Since the beginning of the Drug War, more than 250,000 murders have been reported, most of which have never gone to trial. 
One of the most endangered zones of this conflict is the northeastern coastal state of Tamaulipas, on the border with the United States. With a land area of $80,249 \mathrm{~km}^{2}$ and a population of over three million, Tamaulipas is a transit zone for drugs, weapons, and people, with a strong presence of the Narco cartels that have infiltrated all levels of government. In 2010, the Inter-American Commission on Human Rights declared it a "Silenced Zone": one of the most dangerous places in the world to practice journalism. ${ }^{1}$ Reports of attacks on newspaper offices, and of journalists being threatened, kidnapped, and killed, have mounted. The main consequence of this journalistic silencing is a lack of local news coverage. The remaining media outlets report international and national matters, yet neglect local concerns. In a region beset with widespread corruption, the absence of free journalism is yet another symptom of Narco reign.

In 2012, the Teatro para el Fin del Mundo (TFM) collective (translated: "The End of the World Theatre") launched a theatre festival that utilized abandoned spaces located in the industrial port city of Tampico. This urban area has been a historical epicenter of Mexican social upheaval. Its nineteenth-century downtown area - once the most important port of Latin America and called "the Mexican New Orleans" during the 1920s — seemed forsaken, its modern architecture buildings decaying under the pressures of time, nature, and humidity. With the TFM festival, these same buildings inadvertently became defiant countercultural symbols.

Successive editions consolidated the TFM Festival as a laboratory of formal experimentation for artists. It established its own common aesthetic, distinguished by post-apocalyptic and tropical scenarios, the use of fire onstage, slender scenographic resources, and the constant risk of Narcoviolence around the artistic activity. Among the participating artists, it was common to talk about a "TFM way of art," while its influence started to permeate the peripheral theatre scene in Mexico, eventually leading to the formation of an affiliate group in Uruguay.

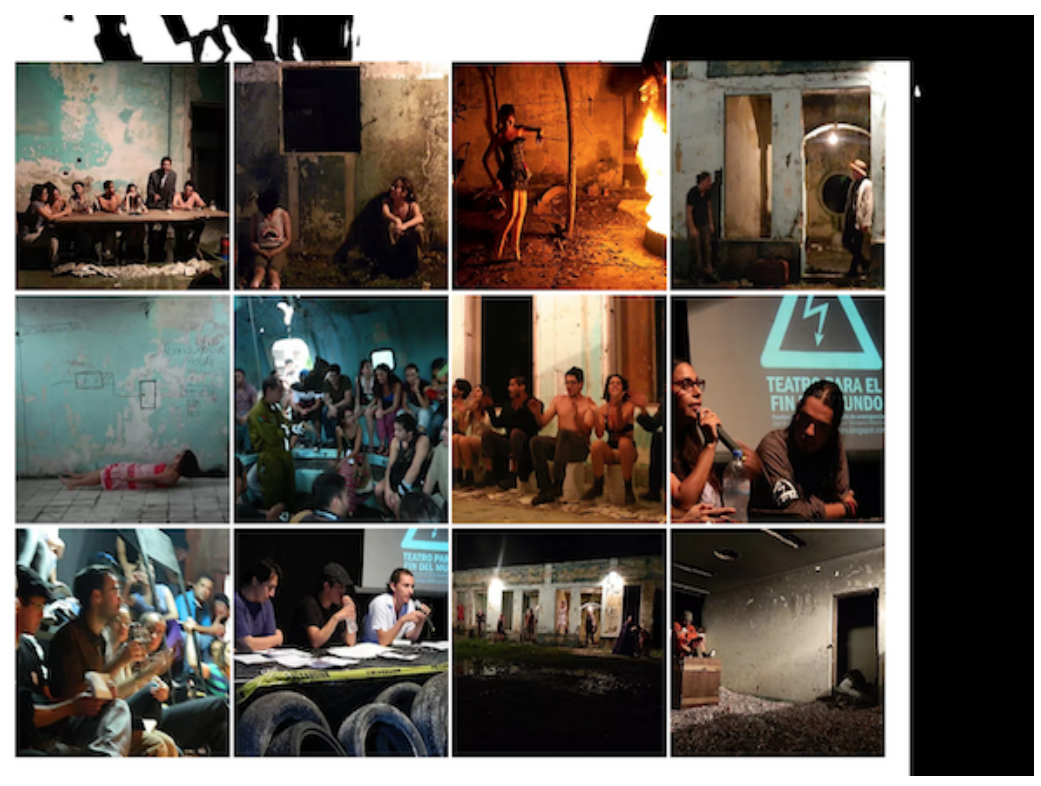

Figure 1. TFM first festival in www.teatroparaelfindelmundo.com 
But neither success nor international recognition insulated TFM members from the effects of the Drug War. The festival's ephemeral nature and existence on the fringes of official cultural circuits continuously endangered its long-term feasibility. Also, since the context was an intense and unpredictable stimulus for the participants who arrived from multiple countries, it was an unceasing risk factor for the organizers, who remained in the city after each festival.

In 2015, its director, Ángel Hernández, synthesized this condition as follows:

Our task in this war was to offer one testimony regarding the hidden files that registered the names of hundreds of murdered and disappeared people, victims of the necessity of feeding a regime based on the extermination. The people who disappeared, along with their spaces, during this war are now, in Tamaulipas, the voice of a silence that is yet to be acknowledged. ${ }^{2}$

Originally, they only wanted to organize a theatre festival in their hometown. In the end, they found themselves challenging the mafia cartels for the territory.

\section{Hauntologies}

In 2015, TFM invited us - the Stultifera Navis Institutom - to develop a research project in their festival. Our collaboration was part of a program of residences that TFM promotes to go beyond the single adaptation of theater presentations to abandoned spaces, giving them a sensitive treatment and stimulating research in the social context of Tampico. Once there, we were taken to a three-story abandoned building which was initially built as a luxury condominium seven decades ago, but today is completely overrun by nature. The building is now home of bats and weeds, but with the remains of fancy tapestry and sumptuous bathrooms, and the first thing that caught our attention was the urgency of thinking about "the ruin" as a space that suffers a crisis of representation. This is a space that is violently ejected from history, and a direct consequence of it; it is an anachronistic space, thereby a false memory.

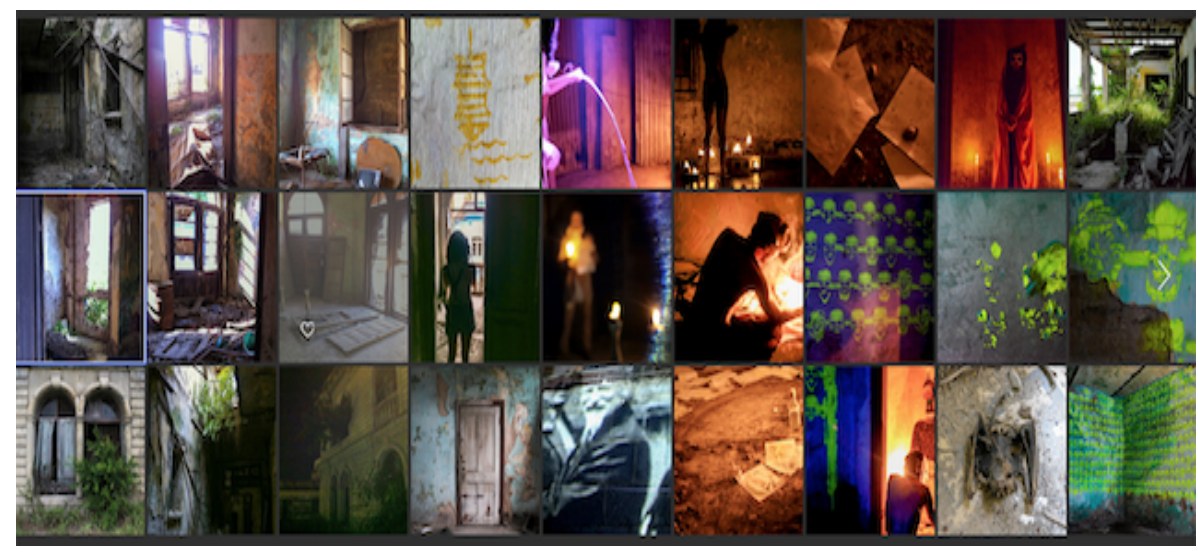

Figure 2. “Voices of water," images from the theatre installation in stultiferanavis.institute 
Immediately, Georges Didi-Huberman's proposal in The Surviving Image came to mind. ${ }^{3}$ Ruin expresses itself as a mixture of spectral images emerging from oblivion, but with the capacity to question hegemony and establish a new tradition. It constitutes a "renaissance of images," as we understand through Didi-Huberman's reading of Aby Warburg's proposal of the history of art. Thinking in terms of ghosts, Jacques Derrida's concept of "Hauntology" also came to mind. ${ }^{4}$ A spectral event is not a repetition or recreation of the past, but rather, the staging of a presence that challenges the "alives" in the present. It is a historical event, a theatrical event—and perhaps, an image.

But more than anything, it was the reflections on Shakespeare's Hamlet and its reading as part of the creative research process that captivated our imaginations. With a countless list of theoretical reflections on Hamlet's archetype, the tragedy was revealed to us as a methodological tool to identify hidden secrets on the dampened walls of the building where we were staging our scenic installation, and to interpret the remains of a luxurious era, the figure of a lost city, as that of a dead king willing to speak. The ghost of a forgotten, prosperous urban area was now transformed into a battlefield. Specters of old injustices were prevented from vindication by their heirs, due to their abandonment of the geography in which they occurred.

Could we think of Shakespeare as a theorist of the Revolution? This is an idea not so remote from Karl Schmitt's interpretation of Hamlet in the context of the reign of James VI and I. ${ }^{5}$ But we were so far removed from Britain and its Golden Age. In the suffocating heat and humidity of the postmodern tropical port of Tampico, the spectral calling suggested that "something was rotten in the state." But Denmark was now everywhere. As Derrida instructed, to engage in hauntology is

to learn to live "with" ghosts, in the upkeep, the conversation, the company, or the companionship, in the commerce without commerce of ghosts. To live otherwise, and better. No, not better, but more justly. But "with them." No "being-with" the other, no "socius" without this "with" that makes "being-with" in general more enigmatic than ever for us. And this being-with specters would also be, not only but also, a "politics" of memory, of inheritance, and of generations. ${ }^{6}$

That was not only an academic pamphlet for the post-Marxist historians but a very concrete proposal for a time and geography "out of joint." Maybe the less relevant fact there was the theatrical result in the language of art-a scenic installation-more relevant was the calling of history as a succession of theatrical uprisings. ${ }^{7}$ After we were finished, the attending public wanted to share their memories about the old days. That, for us, was an encouragement to think we could induce the so-called "injunction" with what Derrida defines as the quandary that emerges with the ghost revelations: "To be or not to be?"

That was how a speech given by Leon Trotsky upon his arrival in Mexico could speak, in 2015, with so much clarity about the recently discovered anonymous graves in Tamaulipas, which contained tens and hundreds of corpses buried by the Narcos. ${ }^{8}$ Certainly, in this case, the historical reflection was limited to an independent and emergent private spectacle. As a result of two successive residences, a workshop, and the thoughts that resulted from them, we developed a 
practical methodology for the production of Hauntologies. We understood that they could be used for a multiplicity of art expressions, but we were also aware that its test in the public space, as in history, was still unresolved.

\section{The Ghost Newspaper}

In 2016, TFM once again invited us to their festival, intending to give continuity to our Hauntological research. This time, the festival was going to be developed not in different spaces, but only in one: an imposing four-story building in the main street of the city of Tampico. This place was once home to an old news journal, El Heraldo, one of the most famous Mexican newspapers in the mid-twentieth century, which shut down thirty-five years ago as a result of the longest labor strike ever documented in Mexico (twenty-two years). Property of an extravagant businessman (and an enemy of the state oil company's trade union), the building still shows off its marble two-level windows, a sign of an antique opulence and its hegemonic position in the local media context.

We informed the TFM collective that we were not going to make a scenic presentation. However, we would require an office, a printing press, and volunteer journalists. We were going to revive the newspaper.

Derrida describes three different stages in the production of the spectral appearance: 1) "the mourning," 2) "the voice," and 3) "the work." "Following those steps, we identified the remains of the newspaper, its history, and its death. We identified "the marks of its name": the articles against the official political party and its clear manipulation in favor of private companies. We replicated its design, its name, and its practice of faking news, taking it to radical consequences. We did "let the thing work." For three days, we established the Ghost Newspaper in its original installation, since the theatre festival was happening inside the very building where El Heraldo was published. We established an emergent editorial office, where every night we designed the front page, discussed the editorial letter that would be sent to press at daybreak, and distributed copies in the morning. Once again, El Heraldo would be a printed journal, and it would also mark the return of the ancient one. Its distinction: all of its news might have been invented. ${ }^{10}$

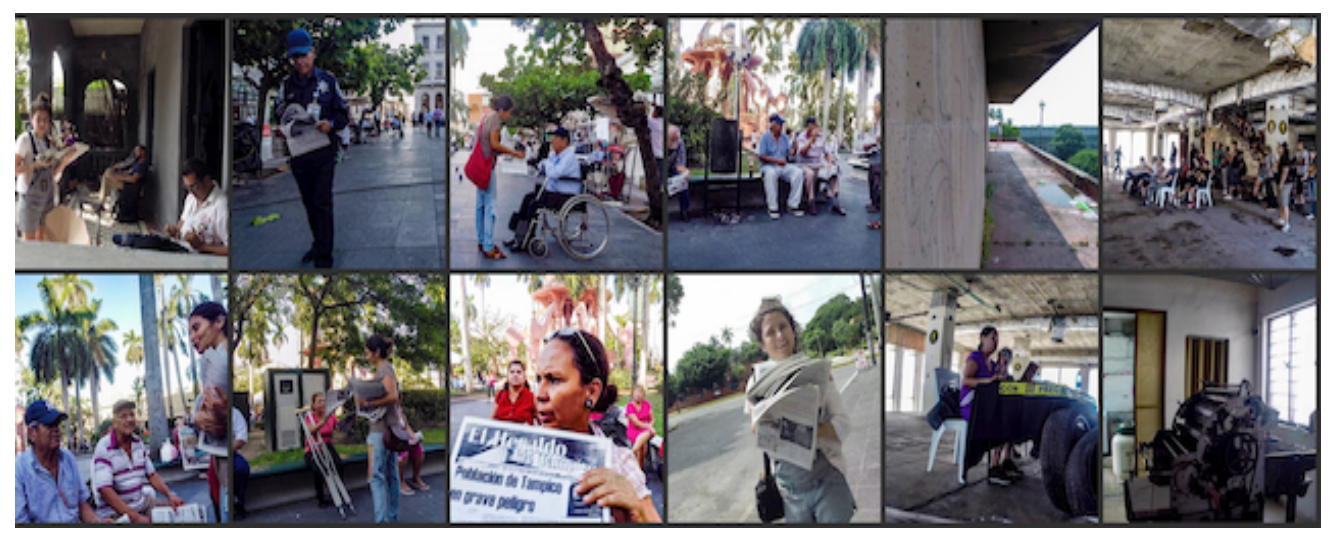

Figure 3. “Resurgence of El Heraldo de Tampico," records of site-specific intervention in stultiferanavis.institute 
So there it was: poetry on the front page, fake news everywhere, fake publicity, fake advertising, fake political motivations accompanied by fake political movements; a fake city to report, to inform, an allegorical city, maybe fictional, hopefully better.

Once on the streets, the effect was immediate: people reacted with enthusiasm, surprise, curiosity. An older adult, who used to be a newspaper vendor when he was a child, asked to distribute the revived publication. In a downtown traditional café, the elderly started to discuss the news that appeared in El Heraldo. Some were offended by the fact that we were distributing fake news in the main plaza. In just a few days, without noticing, we had earned the position of a hegemonic medium in a city marked by the absence of local news.

It was not only the effect of nostalgia at work, but a legitimate reclaiming of the local perspective. We did not foresee this when we proposed the Resurgence of El Heraldo, but it emerged as the project's greatest impact, since we were playing with the existence of a fake public space.

\section{Fake News Era}

An emergent property of this hauntological "experiment" was the resurgence, not only of a newspaper but the validity of the local perspective and deontological debates in the digital media news era. Following the editorial pages of the resurged Heraldo, we find the dramaturgic evolution of this reflection:

It will be questioned, with all reason, why to reestablish a printed news media. [...] Thanks to the communication technologies, in just seconds, we could know with all detail and in video records what is happening in other parts of the world. We did learn to see reality differently. In that sense, the story machine that used to be the printed newspaper seems today as obsolete in informing as a cuneiform tablet exhibited in a museum. But even in that case, to observe the hieroglyphics and ask about their meaning seems legitimate: we must question which absences it refers to [...]. Even if we have lost the purpose of a journal, we persist in the ceremonies that implicate its existence [...]. Perhaps we still don't need the truth of journalism, but we definitely need its rites. (El Heraldo de Tampico, October $6,2016) .^{11}$

In its resurgence, El Heraldo was not only a site-specific intervention in the public space but a reflection on journalistic activity itself. In a political moment where fake news seems to dominate the public sphere in the wake of digital media, the fake printed journal — or, we might say, the spectral voice - stands as a Shakespearean method for revealing hidden truths. 


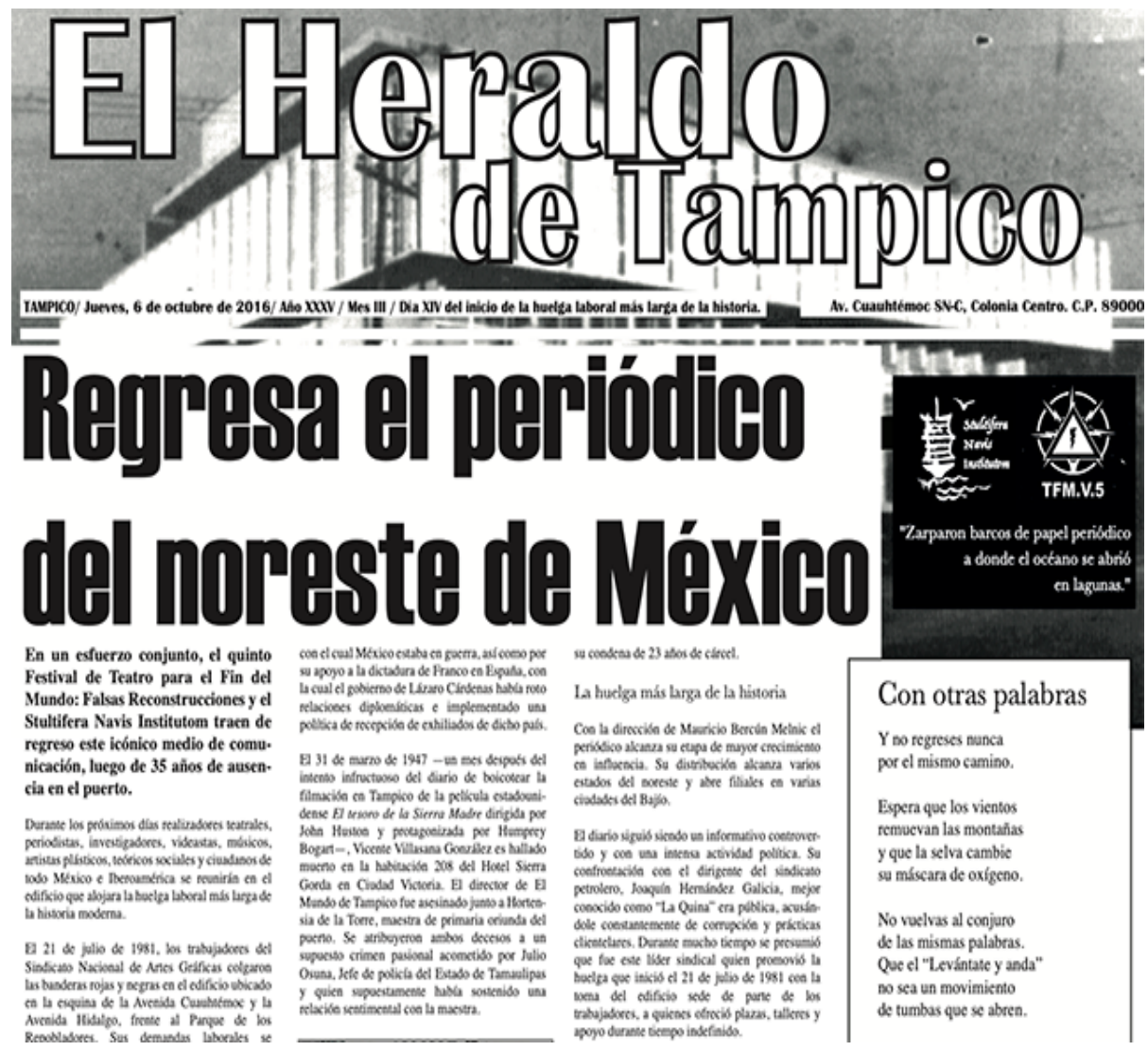

\section{Figure 4. “Mexico's Northeastern Journal returns," the front page of El Heraldo de Tampico, October 6, 2016}

We could follow here Georges Didi-Huberman's idea about the "symptoms in the ambiance," as a consequence of the "footprints of the past," "signs of a presence": a phantom. We found, when the specter is there, a "masked reality"; a survival that confuses history. ${ }^{12}$ That said, El Heraldo's resurgence didn't produce a Hauntology, but rather, it revealed the presence of it in daily life, with the persistence of an enormous unused building in the middle of Tampico's downtown, as a "retrogressive architectural form," "a heterochrony," and "a living fossil." The disconcerting "armor" (delineating a figure) of a lost journal. Over and above that, El Heraldo's resurgence produced a fiction. Its essence: a printed artifact to be tested in its verisimilitude in a very particular context. But, what is a fiction in the context of a war?

A significant reference point for this project is the Yes Men's "Iraq War Ends" special edition of The New York Times, which was launched a week after the election of President Barack Obama. ${ }^{13}$ The Yes Men's project was at once the projection of a political possibility and a demand, both spirited articulations for an undetermined future. In contrast, El Heraldo did not outline any prospects: as every ghost, it was a voice unable to make plans. The question remains: did its appearance produce any effects? 
In his revision of the Marie-Laure Ryan and Pierre Lévy's' "virtuality” concept, Gordon Calleja ${ }^{14}$ recovers the fictional world of Jorge Luis Borges's short story "Tlön, Uqbar, Orbis Tertius," 15 as an example of a reality-altering form. This form emerged from a text - in this case, an encyclopedia entry - that refers to the fictional nation, world, and universe of which the narrative voice has only fragmentary knowledge based on information hidden in different publications by a secret society through the centuries. However, the existence of this fictional world seduces those who know about it, which makes Borges conclude that sooner or later Tlön will replace reality. The world of Tlön is a fiction "that becomes increasingly real through an act of conscious creation by an expanding group of followers dedicated to its description, inscription, and dissemination."16 Borges's short story suggests that both fictional representations and reality may be part of a shared symbolic system in which they mutually disrupt one other. Referring to the same Borges text, Ricardo Piglia suggests that the most pivotal aspect of the story is that the fake encyclopedia entry which began the search of Tlön is lost: "It is not the real what burst in, but the absence, a text we don't have but which search takes, like in a dream, to the encounter of another reality." ${ }^{\prime 17}$ Piglia imagines a reader trapped in virtuality yet dwelling the real. He offers another noteworthy example of this condition: Shakespeare's Hamlet, which defines its protagonist as pretending to go mad after his encounter with a ghost, and he draws an analogy to the condition of the reader themself. When Hamlet is asked about the content of the book he is reading, he simply answers: "Words, words, words."

On its final edition, the resurged Heraldo revealed itself as a fake journal and elaborated on its own condition in the context of the proliferation of contemporary journalism:

For in this moment, the falseness of this reconstruction will become evident. Over the last days, El Heraldo reappeared, briefly, as a fake news journal.

To prepare a daily journal that aspires to hold the lie could be thought, in a very first moment, as an insolent and vain exercise. However, we understand that the pretension to hold "the truth" against the technical and reach capacity of the great media, with our exiguous resources, would be ridiculous and, finally, impossible. Thereupon, we challenge them the ability to lie better (El Heraldo de Tampico, October 8, 2016). ${ }^{18}$

"Lie better" would mean in these terms, the effort to release through a fake-news artifact a sophisticated fiction: the resurgence of an old newspaper. In the troubled and confusing context of a war, an unorthodox strategy to gain fiction readers.

\section{And the War Remains...}

To identify these actions as a successful strategy to defend free journalism or to protect cultural heritage in the violent contexts of a third-world country would be misleading. More than a decade after the beginning of this Mexican Drug War, despite political alternation, multiple efforts from society, hundreds of artistic initiatives, and all sorts of social strategies that try to reduce or understand violence and to activate memory mechanisms against it, the war remains, and its effects are increasingly worse. 
Recently, the "spectrality" of Mexico has been fetishized as a cultural product to be exported with the international branding of the mestizo tradition of "Día de Muertos," as it appears in mainstream movies as Pixar's Coco (2017) and James Bond: Spectre (2015). ${ }^{19}$ As the anthropologist Claudio Lomnitz describes in detail, the origins of this tradition are not pre-Hispanic, but modern, and its celebration has intensified during periods of increased violence, such as the Mexican-American War (1846-1848), the Mexican Revolution (1910-1920), and today, the Drug Wars (2006present). ${ }^{20}$ Despite our efforts to the contrary, we may be reproducing the popular expression of a social symptom: we watch ghosts instead of seeing them as the effects of the consolidation of a perpetual state of war in these territories.

Ángel Hernández reflects about TFM in terms of this failure in the text "We didn't really want to be here" after the collective had to abandon some of the previously recovered spaces because of the pressure of the violent context.

In the first half, the story does not talk about us; there are no records or testimonies that can establish that one day we met here, dirty, tired of so much death, to rest among the rubble of what was left of the city. Then, the second half does mention us. Something about us saying that we are defeated, that they wounded us with an irreparable, treacherous shot and then we declared that, yes, that that was our will, that it was our collective intention to lose. That they would have no problems with us. That we were accomplices with cowardice. That in this war, we neither wanted nor planned to win anything. Maybe to forget, maybe to have the luck of not looking. That we were grateful for considering ourselves alive, while millions disappeared, violated, and murdered in this country. That we did not want to win because we had been taught that way, and we understood it was needed in order to avoid a greater conflict. That we would be better off by representing the artist's idiotic role. That in obedience, we understood a clear redemption's manifesto and the preservation of this exhausted discourse. That we were afraid, and it was fear that made us lose control in the moment of thinking about theatre as an act of survival capable of revealing the ghosts of the old failed rebellions of the world. ${ }^{21}$

So thinking now about art and social change beyond the different tools and strategies, either based on the use of the new technologies or the summoning of spectral forces, may not be the sharing of a sum of "know-how" strategies, but a retrospective of the persistent tragic condition expressed in history, and the strategies used by fiction creators and spectators to survive. "Pretending to be mad" in troubled times as a way to preserve life....

Didi-Huberman bases his redefinition of art history based on Aby Warburg's concept of "images in history." Warburg's theory resulted from his 1923 experience of some weeks with the Hopi Indians - also called "Pueblo" Indians - in New Mexico, a culture identified by their peaceful and austere way of being. The German historian identified in them the prevalence of some images, as allegorical symbols, that helped the Hopis activate collective memory and speak with their ancestors, which he related to the survival of pagan ideas in European Renaissance art. ${ }^{22}$

In December of 2018, I came to the Hopi village of Oraibi, Arizona, the oldest continuously inhabited settlement in America and now part of a lonely Native reservation in the desert, hoping to discover what motivated Warburg to center his interpretations on survival images. The first thing that captured my attention was the strict regulation about taking photos or making any drawings: it is prohibited. Similarly, the Hopis do not write down their legends and traditions. Their rationale 
is to force themselves to transmit knowledge orally and from memory from one generation to the next, and not through what Western civilizations call media or "cultural supports" (paintings, books, photographs, etc.), thus enforcing stronger bonds between their own traditions and knowledge.

After the first photographs of their territories were taken at the beginning of the twentieth century, including by Warburg himself, the Hopi understood that portraits and texts would deteriorate their dialogic tradition and even "capture" their dead relatives and spaces in images, keeping the departed away from them. We mustn't see this decision as the effect of superstition, but rather a profound reflection of the Hopi understanding of the passing of time and memory. As linguist Luis Fernando Lara suggests, "events" for the Hopis could form part of a semantic of space.

Distance could work both in geographical and in concurrence terms, resulting in a "no-time" form of enunciation - based on who enunciates - that understands what happened in their own ancient myths as nearer than what is published in the morning's newspaper. ${ }^{23}$

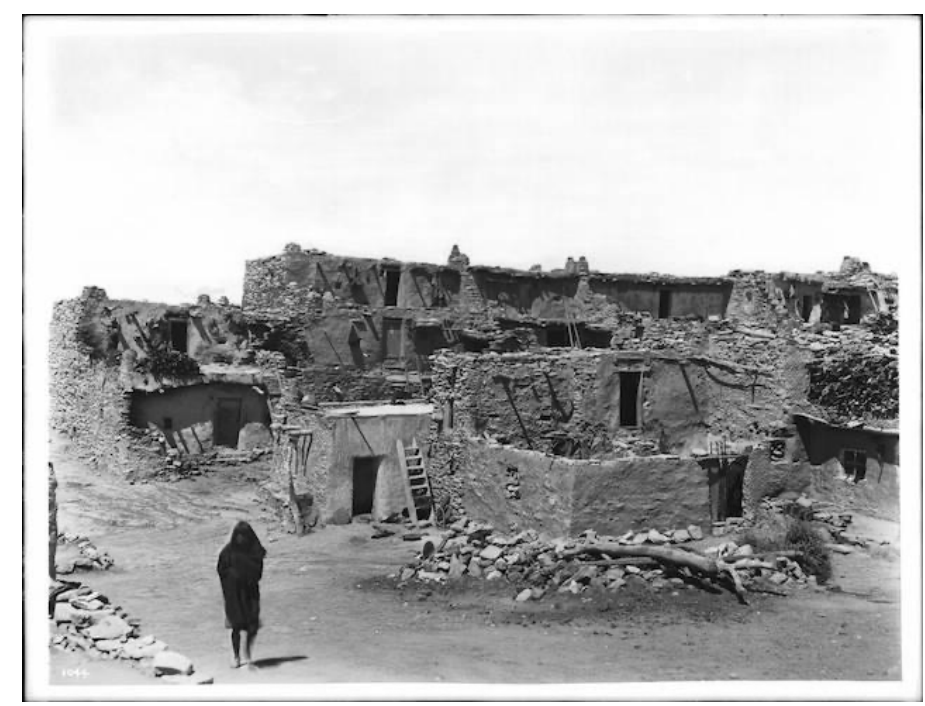

Figure 5. C.C. Pierce, New Adobe Dwellings in the Village of Mishongnovi, 1900.

Seen like this, "anachronistic images," far more than a desirable form of negotiation with the tradition, show themselves as a neutralization form of the communitarian experience. For the Hopis, their identity remains neither in images nor in written texts, but in life itself: a dialogue with their territory. Symbols of their ancient petroglyphs are far from being forms of mediation. Instead, they are the sign of the prevalence of their atemporal "ethos." Warburg's understanding of the Hopis was all wrong, ${ }^{24}$ so was Didi-Huberman's, and ours.

We could think that this doesn't affect the theoretic architecture of ghosts in history made by postMarxist authors, but we find here a suggestive critique of it. Oraibi is a living settlement, but also an archeological site. For Hopis, there is not any dissociation between heritage and daily life. From 
a culture that believes that time is not linear, the apparition of ghosts through a newspaper may seem like a symptom of a community that has forgotten to inhabit ruins and nature.

Hamlet's tragedy may also be an expression of the modern abandonment of the mythical understanding. We watch ghosts instead of realizing that perhaps it was "the intrusion of time" that took us "into the play" and "out of joint." Or, as Suely Rolnik diagnoses the colonial-capitalistic scene, there is a dominant tendency of our culture to enhance a melancholic macropolitical messianism embodied by ghosts, that, in the end, tends to immobilize us. ${ }^{25}$

For the Hopis, we (the Westerners) are living in a false time: history. This is a time defined by material accumulation, and in which we confuse memory with objects - now an uncontainable succession of images. A time where the dead don't return to nature but keep accumulating behind us as an infinite debt. In the record of the dead and still alive newspapers, we could find the pile of their complaints.

Perhaps the ghost newspaper, El Heraldo, was not an intervention but a mere symptom of a social illness: a silent war to silence the living ones. The indicator that we will remain trapped in the premise of a false dilemma: "To be, or not to be?"26

\section{ACKNOWLEDGEMENTS}

Thanks to TFM's crew for their support, complicity, and inspiring labor; especially to its director Ángel Hernández, whose adventurous spirit provoked these searches. To Vivian Cárdenas for her profitable reading, advice, and conversations. To the Hauntologies' cycle collaborators: Lola Barajas, Raúl Cháirez, Nadia Ross Piña, Tamara Salamandrovitz, Fernanda Soria Martínez, Estefanía Vega (Voices of Water), Ana Lucía Heredia (The Resurgence of El Heraldo de Tampico), Domingo Balleza, Emmanuel Frías, Juan Ferrari, Luz Andrea Heredia, and Rodrigo Vite Deutsch (both cycles). And to Eustolio Pardo (besides all previous), pilgrimage companion in the way to Oraibi.

On July 30, 2013, the scenic artists Fernando Landeros, Jefté Olivo, and Omar Vázquez were kidnapped and disappeared while they were developing a scenic project in the streets of Tamaulipas. This text is dedicated to their memory. For more information, visit: www.elcaminohaciathar.blogspot.com.

\section{ENDNOTES}

1. James L. Cavallaro, et al., Silenced Zones: Highly Dangerous Areas for the Exercise of Freedom of Expression, Washington, DC: General Secretariat, Organization of American States, March 15, 2017.

2. Ángel Hernández, "La otra guerra" [The other War], Paso de gato. Revista mexicana de teatro Year 13, No. 61 (2015): 62-63.

3. Georges Didi-Huberman, La imagen superviviente. Historia del arte y tiempo de los fantasmas según Aby Warburg [The Surviving Image: Phantoms of Time and Time of Phantoms: Aby Warburg's History of Art], trans. Juan Calatrava (Madrid: Adaba, 2009). 
4. Jacques Derrida, Spectres of Marx. The State of the Debt, the Work of Mourning and the New International, trans. Peggy Kamuf (New York and London: Routledge, 2006).

5. Schmitt, Carl, Hamlet o Hécuba, la irrupción del tiempo en el drama [Hamlet or Hecuba: The Intrusion of the Time into the Play], trans. Román García Pastor (Valencia: Pre-Textos, 1993).

6. Derrida, op. cit., xvii-xviii.

7. Stultifera Navis Institutom, "Voces de agua: El teatro de fantasmas del Heroico puerto de Tampico" [Voices of Water: The Ghost Theatre of the Heroic Port City of Tampico], accessed June 7, 2020, https://www.stultiferanavis.institute/voces-del-agua-el-teatro-de-fantasm

8. Leon Trotsky, "Declaraciones en Tampico, 9 de enero de 1937" [Tampico Speech, January 9, 1937], accessed June 7, 2020,

https://www.marxists.org/espanol/trotsky/ceip/escritos/libro5/T08V112.htm

9. Derrida, "Injunctions of Marx", op. cit., 1-60

10. Stultifera Navis Institutom, "The Resurgance of 'El Heraldo de Tampico,"” accessed June 7, 2020, https://en.stultiferanavis.institute/resurgimiento-de-el-heraldo-de-tamp

11. Stultifera Navis Institutom, El Heraldo de Tampico, October 6-7, 2016, accessed June 7, 2020, https://drive.google.com/drive/folders/0B96R-UV25HQ6N1R3VmtLS1hiZU0

12. Georges Didi-Huberman, op. cit.

13. Yes Men, “Hijinks," New York Times Special Edition, November 2008, accessed April 25, 2021, https://theyesmen.org/project/nytimes

14. Gordon Calleja, "Of Mirrors, Encyclopedias, and the Virtual", in Cy-Borges: Memories of the Posthuman in the Work of Jorge Luis Borges, eds. Stefan Herbechter and Ivan Callus (Lewisburg: Bucknell University Press, 2009), 88-107.

15. Jorge Luis Borges, Ficciones, (España: Penguin Random House Grupo Editorial, 2012),

Kindle edition.

16. Gordon, op. cit.

17. Ricardo Piglia, “¿Qué es un lector?”, in El último lector (México: Penguin Random House, 2015), 17-34.

18. Stultifera Navis Institutom, El Heraldo de Tampico, October 6-7, 2016, accesed June 7, 2020, https://rive.google.com/drive/folders/0B96R-UV25HQ6N1R3VmtLS1hiZU0

19. Nataniel Parish Flannery, "Pixar's 'Coco' Celebrates Mexico's Day of the Dead Culture," Forbes, November 27, 2017, accessed June 7, 2020,

https://www.forbes.com/sites/nathanielparishflannery/2017/11/27/pixars-coco-celebratesmexicos-day-of-the-dead-culture/\#55fd77a81067

20. Claudio Lomnitz, Death and the Idea of Mexico, (Cambridge and London: MIT Press, 2005).

21. Ángel Hernández, Revista Levadura, October 2016, accessed June 7, 2020,

$\mathrm{http}$ :/revistalevadura.mx/2016/10/22/quisimos-en-realidad-estar-aqui-teatro-fin-del-mundo/

22. Aby Warburg, El ritual de la serpiente [The Snake's Ritual], trans. Joaquín Etorena

Homaeche (Mexico: Sexto Piso, 2004).

23. Luis Fernando Lara, "La significación del tiempo en las lenguas" [Signification of Time in Language] Estudios de Lingüística Aplicada, año 29, número 53, julio de 2011, 99-115

24. A detailed account on Warburg's misunderstandings of Hopis can be found in David

Freedberg, "Pathos a Oraibi: Ciò che Warburg non vide" [Pathos at Oraibi: What Warburg did Not See], Lo Sguardo di Giano, Aby Warburg fra tempo e memoria, ed. Claudia Cieri Via and Pietro Montani (Turin: Nino Aragno, 2004), 569-611.

25. Suely Rolnik, "The Spheres of Insurrection. Suggestions for Combating the Pimping of Life," e-flux Journal, No 86, Nov. 2017, accessed June 7, 2020, https://www.e- 
flux.com/journal/86/163107/the-spheres-of-insurrection-suggestions-for-combating-the-pimpingof-life/

26. Our reference version is William Shakespeare, Hamlet, Prince of Denmark, annotated by

Michael J. Cummings, ed. W.J. Craig [1914 Oxford Edition], accessed June 7, 2020,

http://shakespearestudyguide.com/Hamlet\%20Text.html

\section{AUTHOR BIO}

Fernando Martín Velazco is a Mexican writer and captain of the Stultifera Navis Institutom, a multidisciplinary research platform based on an expeditionary method. His work focuses on the field of expanded arts and has been presented in Mexico, the United States of America, Uruguay, and the former Yugoslavia, highlighting the cycle of annual expeditions "The Leviathan's Playing" (2017-2021) that carry out cultural and symbolic research with grey whales. He was part of California's 2020 Djerassi Resident Artists Program selection, and received second prize from Barcelona's Quo Artis Award 2020 for Production in Art, Science, and Technology. 